\title{
PENANAMAN NILAI KARAKTER GEMAR MEMBACA BERBASIS PEMBIASAAN DAN KETELADANAN TERHADAP KEMAMPUAN BERBAHASA SISWA SEKOLAH DASAR
}

\author{
Efi Ika Febriandari \\ PGSD, STKIP PGRI Trenggalek, Indonesia \\ efi.ika.f@gmail.com
}

\begin{abstract}
Advantage the article has the purpose of describing how to instill reading like the charater of an avid reader and habituation which have impact on children's language skills. Based on the literature reviews show that the elementary school children's reading interest is very low. It is influenced by the lack of awareness in reading importance of reading and external support such as the direction and guidance of parents and teachers, the availability of reading material, and the attractiveness of available books. For this reason, there is something that it takes for habituation and exemplary efforts that are made both from the awareness of oneself, family, teachers and the surrounding environment so that children are accustomed to reading books and make children to enjoy reading books which in turn can increase language skills in children. Habitual and exemplary methods are effective ways to instill the character of reading fondness. The more someone likes to read, the more knowledge is gained. To inculcate the reading fondness character values, it takes habituation and example to realize the culture of fond reading. The fond reading character is a form of language skills development. The more skilled a person in language, the more brilliant, and clearer the way he/she thinks because their processes reading there is a process of critical thinking.
\end{abstract}

Keywords: Reading fondness character values, habituation and example, language skills 


\begin{abstract}
Abstrak
Artikel ini memiliki tujuan untuk memaparkan cara menanamkan gemar membaca berbasis keteladanan dan pembiasaan yang berdampak pada keterampilan berbahasa anak. Berdasarkan kajian pustaka minat baca anak SD sangat rendah, hal tersebut dipengaruhi kurangnya kesadaran diri akan pentingnya membaca dan dukungan dari luar seperti arahan dan bimbingan orang tua dan guru, ketersedianan bahan bacaan, dan kemenarikan buku yang tersedia. Oleh karenanya perlu ada upaya pembiasaan dan keteladanan yang dilakukan baik dari kesadaran diri sendiri, keluarga, guru dan lingkungan sekitar agar anak terbiasa untuk membaca buku dan menjadikan anak menggemari membaca buku yang nantinya dapat menambah kemampuan berbahasa pada anak. Metode pembiasaan dan keteladanan merupakan cara yang efektif untuk menanamkan karakter gemar membaca. Semakin seseorang gemar membaca, maka semakin banyak pula pengetahuan yang diperoleh. Untuk menanamkan dasar karakter suka membaca perlu adanya pembiasaan dan keteladanan untuk mewujudkan budaya gemar membaca. Karakter gemar membaca, sebagai wujud pengembangan keterampilan berbahasa. Seseorang yang semakin cerdas berbahasa, cara berfikir, bertindak, dan tutur kata akan diaplikasikan dengan santun. Itu semua terbentuk karena adanya proses membaca dan berfikir secara kritis.
\end{abstract}

Kata kunci: Nilai karakter gemar membaca, pembiasaan dan keteladana, kemampuan berbahasa

\title{
A. PENDAhULUAN
}

Karakter adalah dasar yang paling utama untuk menanamkan sikap-sikap yang budiman untuk anak. Cara menumbuhkan karakter suka membaca harus dilaksanakan sedini mungkin, terutama di dalam keluarga karena pondasi kali pertama anak suka membaca dan menyukai buku adalah keluarga, selanjutnya di sekolah maupun di lingkungan masyarakat. Penanaman karakter gemar membaca membutuhkan kesadaran diri sendiri dan tentunya didukung keteladanan yang baik dari ketiga lingkungan tersebut, selain keteladanan juga diperlukan konsisten dalam proses pembiasaan. 
Seperti pernyataan Mulyatiningsih ${ }^{1}$, dalam proses pembentukan karakter baiknya dilakukan secara terus menerus yang meliputi tiga komponen diantaranya lingkungan yang paling dekat dengan anak (keluarga), lingkungan pembelajaran yang ada di sekolah dan lingkungaan bersosial dan bermasyarakat.

Perilaku dan kebiasaan orang dewasa baik di rumah, di sekolah maupun di masyarakat orang yang bisa diteladani atau ditiru setiap sikap, perilaku dan kebiasaannya. Anak akan senantiasa meniru dan menilai perilaku orang di sekitarnya. Melihat dan mendengar kebiasaan yang dilakukan orang-orang di sekitarnya tanpa mereka sadari akan terus terulang berkali-kali dan menjadi kebiasaan. Oleh karena itu perlunya pemberian contoh dan keteladanan untuk menyukai kegiatan membaca yang nantinya menjadi gemar membaca bagi orang dewasa di sekitar anak baik itu di dalam keluarga, sekolah maupun masyarakat. Untuk menumbuhkan rasa gemar membaca sejak dini.

Mengacu pada literasi dunia yang telah dilaksanakan Central Connecticut State University di bulan Maret 2016 yang sudah lalu. Minat dan keinginan membaca bangsa Indonesia masih sangat rendah, dari 61 negara Indonesia berada pada posisi 60, hal tersebut sangat memprihatinkan dan harus segera ada solusinya begitupun minat baca anak usia SD. Padahal dengan membaca tidak hanya memperkaya wawasan, namun dengan membaca buku baik untuk kehidupan pribadi maupun sosial yang terwujudkan dalam keterampilan berbahasa. Minimnya kesadaran membaca orang Indonesia terutama anak-anak memiliki beberapa penyebab, misalnya kurangnya kesadaran diri sendiri akan pentingnya membaca, arahan pembiasaan dan keteladanan dari orang tua, pendidik dan adanya buku-buku yang menarik dan akses untuk membaca yang terbatas dapat menjadi penghambat keinginan membaca buku.

Kajian yang telah dilaksanakan memperoleh, hasil dari pelaksanaan penelitian sebelumnya berkaitan dengan penerapan nilai karakter gemar membaca. Seperti hasil penelitian dengan judul““ Kontribusi Penerapan Pendidikan Karakter (Gemar Membaca)

${ }^{1}$ Endang Mulyatiningsih, Analisis Model-Model Pendidikan Karakter Untuk usia Anak- A Rmajwasa”, (Yogyakarta:Jurnal FT UNY. Karang Malang, 2014), hlm. 34

2 Dharma Kesumma,dkk, Pendidikan Karakter (Bandung: PT Rosdakarya Offset, 2012), hlm. 27 
Terhadap Keterampilan Berbahasa siswa Pada Mata Pelajaran Bahasa Indonesia Kelas V MI Darul Hikam Cirebon "yang dilakukan Idah Laili dan Mumtaz Naqqiyah ${ }^{3}$ di tahun 2014 menyatakan bahwa pendidikan karakter rajin membaca memiliki kontribusi pada kemampuan berbasa Indonesia didalam proses belajar Bahasa Indonesia menunjukkan signifikan.

Penelitian yang kedua, pada tahun 2016 juga Puput Perwira Sari ${ }^{4}$ juga melakukan penelitian an yang serupa. Penelitiannya beudul Penanaman Nilai Karakter Gemar Membaca Pada Siswa Kelas IV di MI Maárif NU I Rancamaya Cilongok Banyumas TahunPelajaran 2016/2017 " Pemerolehan dari penelitian yang dilakukan menyatakan penanaman nilai gemar membaca sudah sejalan sesuai apa yang dituliskan pada bab 2 dengan menggunakan berbagai metode diantaranya dengan metode keteladanan, kegiatan spontan, pengondisian dan kegiatan yang diadakan secara rutin dan berkesinambungan..

Penelitian selanjutnya tentang karakter rajin membaca dilakukan pada tahun 2017 oleh Ari Ambarwati. Berjudul“ Penguatan Karakter Gemar Membaca Melalui Cerpen Humor Untuk anak Sekolah Dasar ”. Penelitian ini dilakukan di SD melalui cerita pendek yang bermuatan cerita humor yang ringan dan menyenangkan. Keterlibatan siswa SD dengan cerita humor membuat mereka dapat bersosialisasi dengan teman sebaya maupun orang yang lebih dewasa selain itu dapat melatih siswa untuk gemar membaca yang nantinya akan memupuk kemampuan berliterasi dan menghasilkan SDM yang kritis dan adaptif dengan perubahan jaman. ${ }^{5}$

Penelitian yang relevan keempat dengan judul " Implementasi Gerakan Literasi Sekolah dalam Menanamkan Karakter Gemar

3 Idah Laili \& Naqiyyah, Mumtaz, Kontribusi Penerapan Pendidikan Karakter (Gemar Membaca) Terhadap Keterampilan Berbahasa Pada Mata Pelajaran Bahasa Indonesia Kelas V MI Darul Hikam Cirebon (Cirebon: Jurnal Pendidikan Guru MI, 2014)

${ }^{4}$ Puput Purwita Sari, Penanaman Nilai Karakter Gemar Membaca Pada Siswa MI NU Ramay Cilongok Banyumas Tahun Pelajaran 2016/2017(Purwokerto: Institut Agama Islam Negeri Purwokerto, 2016).

${ }^{5}$ Ari Ambarwati, Penguatan Karakter Gemar Membaca Melalui Cerpen Humor untuk Anak Sekolah Dasar (Malang: Unisma, 2017) 
Membaca Siswa Kelas Tinggi di SD Negeri Sawahan ", yang diteliti oleh Choiri Bayu Respati tahun 2018 dengan hasil melalui pelaksanaan gerakan literasi di sekolah untuk hal menumbuhkan kepribadian rajin membaca, membaca yang secara positif optimal, serta dapat memberikan motivasi dan memberikan semangat baru agar siswa dapat menciptakan karakter gemar memabaca yang baik dan memiliki rasa kecintaan pada buku. ${ }^{6}$

Begitu pula dengan penelitian yang dilakukan oleh Nur Nadif Ulfiah $^{7}$ dengan judul "Penanaman Karakter Gemar Membaca " . Perolehan dari yang diteliti menunjukkan ada beberapa bentuk penanaman karakter diantaranya pembiasaan dalam membaca, saat membaca buku harus memiliki tujuan apa yang akan diperoleh, mampu meluangkan waktu, memberikan label tersendiri disetiap buku, mengadakan sosialisasi baik di lingkungan sekolah maupun di masyarakat, mampu membuat karya ilmiah dari apa yang dibaca. Kendala yang dihadapi dalam penanaman karakter gemar membaca diantaranya kurangnya niat, kurangnya koleksi buku bacaan, kurangnya motivasi yang didapat, ada beberapa buku yang belum terlabeli dan dikelompokkan, kurah faham dalam menuliskan apa yang sudah dibaca, tidak adanya kertas untuk membuat catatan. Solusi untuk hal yang telah disebutkan diantaranya pengadaan dan pengumpulan buku dari medsos, pengumpulan berbagai jenis buku, membuat perpustakaan menjadi menarik agar banyak yang mengunjungi, menyediakan kertas untuk catataan.

Pendidikan karakter merupakan cara dalam menanamkan nilai karakter untuk warga sekolah diantaranya komponen pendidikan. Kesadaran serta perilaku mau melaksanakan nilai berketuhanan terutama kepada Tuhan, terhadap diri, dan orang lain, masyarakat, serta bangsa serta menjadi manusia yang berbudi luhur ${ }^{8}$. Nilai pembentuk karakter berlandaskan oleh agama, pancasila, berbudaya dan bertujuan

6 Choiri Bayu Respati, Implementasi Gerakan Literasi Sekolah dalam Menanamkan Karakter Gemar Membaca Siswa Kelas Tinggi di SD Negeri Sawahan. (Surakarta: Muhammadiyah Surakarta, 2018)

7 Nur Nadhif Ulfiah, PENANAMAN KARAKTER GEMAR MEMBACA. (Surakarta: Muhammadiyah Surakarta, 2014)

${ }^{8}$ Isna Nurla Aunillah,.. Membentuk Karakter Anak Sejak Janin. (Yogyakarta: FlashBooks, 2015), hlm. 14 
kependidikan,. Ada 18 landasan nilai karakter diantaranya: religius, kerja keras, disiplin, ingin tahu, jujur, semangat, berbangsa, toleran, mencintai tanah air, bertanggung jawab, berprestasi, bersosialisasi, komunikatif, perduli terhadap lingkungan dan sesama manusia, mampu berdamai, gemar dan rajin membaca. ${ }^{9}$ Dari nilai karakter di atas peneliti mengkaji 1 aspek nilai karakter yaitu karakter rajin membaca dapat mempengaruhi keterampilan berbahasa. Gemar membaca dapat dideskripsikan suatu rutinitas meluangkan waktu agar dapat membaca beberapa literasi yang dapat bermanfaat dan terdapat kebaikan untuk diri sendiri wujud dan dampak dari pembiasaan tersebut. ${ }^{10}$

Pengertian pembiasaan penumbuhan keterampilan, pengaplikasian lisan dan memperolehkan suatu kegiatan supaya mendapatkan cara yang sesuai dengan keinginan anak dan anak menyukainya. Pembiasaan tidak sekedar menumbuhkan kebiasaan saja namun memiliki arti dalam agar mengakar dalam kebiasaan ${ }^{11}$. Pembiasaan dalam menanamkan dasar karakter rajin membaca baiknya sejak anak usia dini dan perlu adanya berkesinambungan. Perlunya dukungan yang diberikan dari berbagai pihak selain diri sendiri, orang dewasa di rumah, di sekolah sebagai pendidik, dan masyarakat untuk bersosialisasi yang akan berpengaruh terhadap perkembangan keterampilan berbahasa.

Keteladanan, adalah pemberian contoh pembiasaan tingkah laku keseharian. Diantaranya, memuji kebaikan yang dilakukan orang lain, bertutur kata yang santun, rapi berbusana, rajin membaca, disiplin, tepat waktu $^{12}$. Dalam menanamkan dan membiasakan anak agar gemar membaca perlunya keteladanan baik itu orang dewasa sebagai pendidik di rumah, di sekolah dan masyarakat.

Menumbuhkan kebiasaan dan minat membaca sebaiknya sejak dini, mulai anak- anak dalam usia dini terutama usia anak SD. Anak

${ }^{9}$ Thomas Lickona, Pendidikan Karakter Panduan Lengkap Mendidik Siswa Menjadi Pintar dan Baik (Bandung: Nusa Media, 2014), hlm.24

${ }^{10}$ Asmani Jamal Ma'mur, Buku Panduan Interalisasi Pendidikan Karakter di Sekolah(Yogyakarta: DIVA Press, 2013), hlm. 35

${ }^{11}$ Tutuk Ningsih, Implementasi Pendidikan Karakter (Purwokerto: STAIN Press, 2015), hlm. 52

12 Sutarjo Adisusilo, Pembelajaran Nilai Karakter (Jakarta: PT Raja Grafindo Persada, 2014), Hlm. 76 
akan tertarik membaca buku yang ada gambar menarik, berwarna-warni dikemas ringan dan mudah dipahami. Rajin Membaca adalah karaker baik yang perlu ditumbuhkan sejak anak kecil, agar nantinya pada saat anak dewasa anak akan mempumyai keterampilan berbahasa yang tidak perlu diragukan lagi. Manfaat dari membaca ada banyak sekali membaca adalah cendela dumia, alat komunikasi, kreasi, berpengetahuan dan banyak lagi. Kareana dengan membaca otak kita sudah diasah untuk selalu berfikir cerdas dan dapat diaplikasikan dengan cara berbahasa yang cerdas dan santun.

\section{B. PEMBAHASAN}

\section{Karakter Gemar Membaca}

Karakter gemar membaca menurut Kemendiknas adalah kegiatan yang dilakukan dan telah menjadi kebiasaan dengan suka rela mengadakan beberapa waktu untuk membaca buku dan berbagai informasi dibuku, internet, majalah, koran, serta media lain yang memunculkan sutu kebermanfaatan bagi diri sendiri. Karakter rajin membaca adalah kecakapan yang dimiliki seseorang agar dapat faham tentang isi yang ditulis dan mampu untuk menerapkannya ke dalam praktek keseharian. Dari pernyataan tersebut dapat disimpulkan karakter gemar membaca merupakan pernyataan dan kesukarelaan dalam membaca dan memberikan waktu luang agar mampu faham kandungan bacaan dan menerapkannya dalam praktik keseharian. ${ }^{13}$

Langkah-langkah dalam menumbuhkan karakter gemar membaca diantaranya, melalui keteladanan dan pembiasaan memilih bacaan yang menarik, pemberian tugas dalam hal baca tulis dengan cara memperhitungkan waktu yang sesuai dalam pengerjaannya, menyediakan gambar atau audiovisual untuk guru anak usia dini dan SD yang peserta didinya belum biasa membaca, memberikan umpan balik terhadap apa yang dibaca maupun ditulis, mendiskusikan hasil bacaan, menjadikan bahan untuk evaluasi, mengadakan lomba baca tulis berhadiah menarik untuk memotivasi

${ }^{13}$ Sartono.. Membangun Minat Baca Siswa Mengoptimalkan Perpustakaan Sekolah. http://perpustakaan.kaltimprov.go.id/berita-557-membangun-minat-bacasisa- mengoptimalkan-perpustakaan-sekolah. 2014, html, Diakses. Tanggal 2 Juli 2019, hlm. 45 
siswa. $^{14}$

Pembiasaan dan keteladanan merupakan proses penanaman sesuatu yang nantinya akan menjadi kebiasaan, selalu berupaya melakukan tindakan yang terus menerus sehingga terbiasa, dan orang yang melakukannya akan tidak menyadari akan hal sedang dilakukan sudah jadi kebiasaan ${ }^{15}$. Pembiasaan adalah aktifitas yang dilakukan berulang-ulang sehingga kegiatan dilaksanakan jadi kebiasaan yang terus dilakukan. Jadi pembiasaan merupakan proses dan usaha yang dengan cara membiasakan seseorang agar berfikir, berbicara, berperilaku dan berkegiatan apapun dengan pembiasaan yang bagus ${ }^{16}$. Cara membiasakan kebaikan sangat baik dicontohkan pendidik untuk menanamkan pribadi baik bagi anak. Dalam Menerapakan karakter yang baik sebaiknya dimulai sejak dini, agar kebiasaan tersebut melekat sepanjang hayat ${ }^{17}$.

Pendidikan pembiasaan untuk anak dapat dilaksankan antara lain dengan cara dengan kegiatan terprogram dan memerlukan waktu khusus dan dengan cara pembiasaan tidak terprogram. 1) Kegiatan pembiasaan secara terprogram diantaranya biasakan anak agar dapat melalukan pekerjaan sendiri, mendapatkan ide serta dapat mengontruksikan ilmu, keahlian yang dimiliki, biasakan peserta didik untuk selalu bertanya banyak hal agar pengetahuan mereka luas, biasakan peserta didik saling menunjang dan mampu bekerjasama, biasakan peserta didik untuk bertanggung jawab atas apapun yang dilakukan agar mampu berfikir cerdas dan kreatif. 2) Pembiasaan dengan cara tidak terprogram diantaranya a) Rutin merupakan kegiatan yang sudah terjadwal antara lain senam, pemeliharaan kebersihan, upacara, sholat berjamaah, kebersihan jasmani. b) Spontan merupakan wujud kebiasaan yang bukan terprogram dan jadwal istimewa

14 M. Yaumi, Pendidikan Karakter, Landasan, Pilar \& Implementasi . (Jakarta: Prenadamedia Grup, 2014), hlm. 110

15 Depdiknas, Kamus Bahasa Indonesia Pusat Bahasa Edisi Keempat. (Jakarta: PT. Gramedia Pustaka Utama, 2012)Hlm.11

${ }^{16}$ Anis Ibnatul M,dkk, Pendidikan nasionalisme melalui Pembiasaan di SD Negeri Kuningan 02 Semarang Utara. (Jurnal:UNES, 2013), hlm. 1

17 E Mulyasa, Manajemen Pendidikan Karakter (Jakarta: Sinar Grafika Offset, 2012), Hlm. 167 
antara lain pengupayaan karakter sopan, mau memberi salam, antre, jika membuang kotoran pada tepatnya. c) Keteladanan merupakan percontohan dalam yang bentuknya kegiatan pada harihari biasanya, antara lain rajin membaca, berbahasa yang baik, berpakaian yang rapi, $\mathrm{dll}^{18}$

Keteladanan dalam kamus bahasa Indonesia berarti suatu hal atau kegiatan yang baik yang dapat dicontoh dan ditiru ${ }^{19}$. Keteladanan merupakan mendidik dengan menerapkan cara memberikan berbagai percontohan yang sesuai dengan akhlak seperti tingkah laku, yang baik serta mendidik khususnya ibadah dan perbuatan mulia. ${ }^{20}$ Keteladanan merupakan cara pemberian contoh kebiasaan diwujudkan dengan perilaku keseharian misalkan: memakai baju rapi, rajin membaca, bertutur kata santun, memuji setiap kebaikan dan perolehan keberhasilan orang, disiplin dan menghargai waktu. Diperoleh kesimpulan bahwa keteladana memberi contoh dalam mendidik adalah cara mendidik dengan memberikan contoh dimana anak tersebut menirunya baik, tingkah laku, ucapan , cara berfikir maupun praktik di dalam perbuatan yang dilakukan sehari-hari. ${ }^{21}$

Bentuk-bentuk keteladanan yang dapat diterapkan untuk mendidik anak antara lain: 1) keteladanan yang disengaja merupakan keteladanan yang diberikan perintah dan penjelasan agar dapat diteladani sebagai contoh, misalkan pendidik dirumah dan disekolah mencontohkan cara membaca yang benar, sholat yang benar dan melalukan seuatu kebaikan lainnya. 2) keteladanan atau percontohan tak disengaja merupakan percontohan dalam hal pengetahuan, perilaku yang baik, kepemimpinan, kerelaan dan sifat baik lainnya. Dalam hal ini orang tua, guru dan masyarakan baiknya menjadi contoh yang baik karena setiap aktifitas dan

${ }^{18}$ Muhammad Fadillah dan Lili Mualifatu Khorida, Pendidikan Karakter Anak Usia Dini: Konsep dan aplikasinya dalam PAUD (Jogjakarta: Arruzz Media, 2013), hlm. 30

19 Depdiknas, Kamus Bahasa Indonesia Pusat Bahasa Edisi Keempat. Hlm. 13

20 Hasbullah, Dasar-Dasar Ilmu Pendidikan (Jakarta: PT. Raja grafindo Persada, 2012), Hlm. 29

${ }^{21}$ E Mulyasa, Manajemen Pendidikan Karakter (Jakarta: Sinar Grafika Offset, 2012), Hlm. 46 
tingkah laku yang kita atau orang dewasa lakukan akan ditiru dan diteladani oleh anak ${ }^{22}$.

\section{Keterampilan Berbahasa}

Dalam kemambuan bahasa terdapat empat aspek diantarany mendengar, kemampuan bicara, kemampuan membaca serta keterampilan menulis. Setiap aspek daalam berbahasa selalu berkaitan satu dan lainnya. Untuk memperoleh kemampuan bahasa yang sesuai benar kita belajar mengetahui bahasa dari mendengar, berbicara, membaca selanjutnya menulis ${ }^{23}$.

Dalam Abidin $^{24}$ dijelaskan (1) kemampuan menyimak merupakan jenis berbahasa reseptif, menyimak tidak hanya kegiatan mendengarkan saja namun memahamiina juga. Terdapat beberapa keadaan mendengar antara lain, keadaan mendengar interaktif yang berarti terjadi percakapan baik tatap muka maupun telepon, sedangkan non interaktif seperti mendengarkan radio, menonton film, menonton TV dll; (2) kemampuan berbicara termasuk jenis kemampuan bahasa lisan produktif. Terdapat tiga keadaan dalam kemampuan berbahasa berinteraktif misal percakapan tatap muka maupun tidak tatap muka, semi interaktif dalam pidato, ceramah, non interaktif berpidato melalui radio dan televsi; (3) kemampuan membaca jenis kemampuan bahasa tulis yang memiliki sifat menerima. Kemampuan membaca mampu berkembang namun sekarang sering kali dikembangkan terintegrasi antara memabaca dan menulis maupun keempat keterampilan yang menjadi budaya literasi; (4) kemampuan menulis kemampuan jenis tulis yang memiliki sifat mencipkakan karya menulis dikatakan keterampilan paling rumit karena di dalam menulis kita harus kreatif tidak hanya sekedar menyalin kata-kata.

22 Ahmad Tafsir, Ilmu Pendidikan dan Persepektif Islam (Bandung: PT Remaja Rosdakarya, 2005), hlm. 144

${ }^{23}$ Kementerian Pendidikan dan Kebudayaan, Bahasa Indonesia Pengetahuan (Jakarta: Kementerian dan Kebudayaan, 2014). hlm. 25

24 Y. Abidin, Pembelajaran Berbahasa Berbasis Pendidikan Karakter (Bandung: Reflika Aditama, 2012), hlm. 30 


\section{Penelitian Terdahulu yang Relevan}

\section{KESIMPULAN}

Penumbuhan nilai karakter rajin membaca terhadap keterampilan berbahasa perlu dilakukan oleh semua pihak baik dari keluarga, guru dan masyarakat yang tinggal di sekitar dan iklim dari ketiga lingkungan tersebut pada siswa sekolah dasar telah terlaksana sesuai yang direncanakan. Pernyataan tersebut dapat dibuktikan melalui upaya-upaya yang telah yang dilakukan keluarga, pendidik dan masyarakat. Kolaborasi tersebut dapat mengupayakan keresahan dalam karakter rajin membaca.

Diharapkan anak Indonesia mempunyai niat kuat dalam membaca dan mengharapkan semua orang dewasa di rumah, di sekolah, dan masyarakat mampu berperan dengan baik sehingga dapat memberi teladan, memfasilitasi, menetralkan suasana dan mampu mengevaluasi tindakan yang dikerjakan anak agar mengetahu yang baik dan kurang baik.

Dalam proses penumbuhan karakter rajin membaca di sekolah dasar dilaksanakan dengan menggunakan berbagai cara antara lain percontohan/keteladanan, mengondisikan, kegiatan yang terus dilakukan, pembiasaan, kegiatan tanpa direncanakan. Perwujudan karakter rajin membaca disarankan membentuk kerjasama dengan orang dewasa di keluarga agar dapat memantau aktivitas anak di rumah masing-masing. Hal tersebut sangat disarankan karena keluarga dapat mempengaruhi keinginan baca anak. Selain itu di lingkungan masyarakat perlu diadakan acara atau perpustakaan agar masyarakat terbiasa suka membaca terutama anak-anak.

Selain melakukan cara-cara yang ditulis melakukan pembiasaan membaca pada waktu pembelajaran dengan menyediakan bacaan menarik dan anak diminta untuk menjelaskan bacaan yang telah dibaca. Kegiatan ini sebaiknya dilakukan secara rutin agar dapat meningkatkan keinginan baca. Kegiatan tersebut sebaiknya dilaksanakan agar anak terbiasa menyimpan waktunya untuk membaca. Guru juga mengondisikan kegiatan semisal pengecekkan sarana prasarana, membuat ruang baca yang mengasikkan, dengan cara tersebut anak akan senang dan bahagia dalam membaca. 
Penumbuhan karakter rajin membaca tanggung jawab semua pihak baik keluarga, pendidik sekolah, dan sosial masyarakat untuk hal tersebut perlunya kolaborasi antar ketiganya baik internal ataupun eksternal yang secara berturut-turut. Karena upaya menumbuhkan karakter rajin membaca sudah menjadi perhatian khusus di beberapa negara salah satunya Indonesia dalam misi menjadikan generasi yang berbobot.

\section{DAFTAR PUSTAKA}

Abidin, Y (2012). Pembelajaran Berbahasa Berbasis Pendidikan Karakter. Bandung: Reflika Aditama.

Adisusilo, Sutarjo. 2014. Pembelajaran Nilai Karakter. Jakarta: PT Raja Grafindo Persada.

Ambarwati, Ari. 2017. Penguatan Karakter Gemar Membaca Melalui Cerpen Humor untuk Anak Sekolah Dasar. Malang: Unisma

Anis Ibnatul M,dkk. (2013) Pendidikan nasionalisme melalui Pembiasaan di SD Negeri Kuningan 02 Semarang Utara. Jurnal:UNES

Aunillah, Isna Nurla. 2015. Membentuk Karakter Anak Sejak Janin. Yogyakarta: FlashBooks

Depdiknas. 2012. Kamus Bahasa Indonesia Pusat Bahasa Edisi Keempat. Jakarta: PT. Gramedia Pustaka Utama.

E Mulyasa. 2012. Manajemen Pendidikan Karakter. Jakarta: Sinar Grafika Offset.

Fadillah, Muhammad dan Lili Mualifatu Khorida. 2013. Pendidikan Karakter Anak Usia Dini: Konsep dan aplikasinya dalam PAUD. Jogjakarta: Arruzz Media.

Hasbullah. 2012. Dasar-Dasar Ilmu Pendidikan. Jakarta: PT. Raja grafindo Persada.

Kemendiknas. 2010. Pengembangan Pendidikan Budaya dan Karakter Bangsa. Jakarta: Kemendiknas

Kementerian Pendidikan dan Kebudayaan. (2014). Bahasa Indonesia Pengetahuan. Jakarta: Kementerian dan Kebudayaan.

Kesumma, Dharma, dkk. 2012. Pendidikan Karakter. Bandung: PT Rosdakarya Offset.

Laili, Idah \& Naqiyyah, Mumtaz. 2014. Kontribusi Penerapan Pendidikan Karakter (Gemar Membaca) Terhadap 
Keterampilan Berbahasa Pada Mata Pelajaran Bahasa Indonesia Kelas V MI Darul Hikam Cirebon. Cirebon: Jurnal Pendidikan Guru MI

Lickona, Thomas. 2014. Pendidikan Karakter Panduan Lengkap Mendidik Siswa Menjadi Pintar dan Baik. Bandung: Nusa Media

Mulyatiningsih, Endang.2014. Analisis Model-Model Pendidikan Karakter Untuk usia Anak- A Rmajwasa", Jurnal FT UNY. Karang Malang Yogyakarta

Ma'mur, Asmani Jamal. 2013. Buku Panduan Interalisasi Pendidikan Karakter di Sekolah. Yogyakarta: DIVA Press.

Ningsih, Tutuk. 2015. Implementasi Pendidikan Karakter. Purwokerto: STAIN Press.

Respati, Choiri Bayu. 2018. Implementasi Gerakan Literasi Sekolah dalam Menanamkan Karakter Gemar Membaca Siswa Kelas Tinggi di SD Negeri Sawahan. Surakarta: Muhammadiyah Surakarta.

Sari. Puput Purwita. 2016. Penanaman Nilai Karakter Gemar Membaca Pada Siswa MI NU Ramay Cilongok Banyumas Tahun Pelajaran 2016/2017. Purwokerto: Institut Agama Islam Negeri Purwokerto.

Sartono. 2014. Membangun Minat Baca Siswa Mengoptimalkan Perpustakaan Sekolah. http://perpustakaan.kaltimprov.go.id/berita-557-membangunminat-baca-sisa- mengoptimalkan-perpustakaan-sekolah. html, Diakses. Tanggal 2 Juli 2019

Tafsir, Ahmad. 2005. Ilmu Pendidikan dan Persepektif Islam. Bandung: PT Remaja Rosdakarya

Ulfiah, Nur Nadhif. 2014. PENANAMAN KARAKTER GEMAR $M E M B A C A$. Surakarta: Muhammadiyah Surakarta

Yaumi, M. 2014. Pendidikan Karakter, Landasan, Pilar \& Implementasi . Jakarta: Prenadamedia Grup. 